http://dx.doi.org/10.1590/0370-44672014690210

\section{Carlos Barreira Martinez}

Professor Titular

Universidade Federal de Minas Gerais - UFMG

Departamento de Hidráulica

Belo Horizonte - Minas Gerais - Brasil

martinez@cce.ufmg.br

\section{Aloysio Portugal Maia Saliba \\ Professor Adjunto \\ Universidade Federal de Minas Gerais - UFMG \\ Departamento de Hidráulica \\ Belo Horizonte - Minas Gerais - Brasil \\ aloysiosaliba@hotmail.com}

\section{Marcio Figueiredo de Resende \\ Engenheiro Civil \\ Potamos Engenharia e Hidrologia Ltda. \\ Belo Horizonte - Minas Gerais - Brasil \\ marcio.resende@potamos.com.br}

\section{Eder Daniel Teixeira}

Professor Adjunto

Universidade Federal do Rio Grande do Sul - UFRS

Instituto de Pesquisas Hidráulicas (IPH)

Porto Alegre - Rio Grande do Sul - Brasil

eder.teixeira@ufrgs.br

\section{Marcelo Giulian Marques}

Professor Titular

Universidade Federal do Rio Grande do Sul - UFRS

Instituto de Pesquisas Hidráulicas (IPH)

Porto Alegre - Rio Grande do Sul - Brasil

mmarques@iph.ufrgs.br

\section{Introduction}

In the 1970s, Brazil had the second largest industrial park for merchant ships worldwide, losing only to Japan. Currently, the world leadership in shipbuilding comprises Japan, China and South Korea, which are responsible for $80 \%$ of world's production (IPEA, 2014).

The industrial park for ships consists of several manufacturing sectors and assembly sites. Shipyards are possibly the most important places among them,

\title{
Surface drainage system for dry docks in shipyards - Case study of Estaleiro Rio Grande (Technical Note)
}

Abstract

This study aims to present a methodology for the design of a surface drainage system for dry docks in shipyards, taking into account the rainfall intensity at the site, the damping capacity of the hydraulic structures (drainage channels) and the pumping capacity of the pumping system. A case study of a dry dock owned by Estaleiro Rio Grande, located at the state of Rio Grande do Sul, is presented. The results obtained indicate alternatives for channel and submersible pump sizing. These pumps would be used to control the dry dock flooding after an intense rainfall event.

Keywords: shipyards, surface drainage, storm water drainage. because their configuration allows the final construction of boats that will be responsible for transporting thousands of tons of products.

Due to the type of work for which they are to be used, shipyards have specific requirements regarding their operation. Several factors affect the efficiency of shipyard operation, including the possibility of rainfall events that would flood the assembly yards. Small floods can halt the as- sembly line, causing costs and undesirable delays throughout the production chain.

In order to avoid halting the dry dock operations due to a rainfall event, it must be equipped with a storm water management system. This system should allow the maintenance and construction sectors to remain operational, when intense rainfall events occur. It is a common practice to install a set of drainage channels inside the dry dock to collect all 
runoff into a tank, from which the flow needs to be pumped out as the dry dock elevation is lower than sea level.

In this case the drainage channels are for two purposes, namely: (a) to collect storm water and guide it to a tank and (b) to store part of the inflowing water and pump it to an area outside the dry dock.

Since these are small catchment areas, data on intense rainfall are used to determine the flows into the channels. However, in the technical literature, the sizing criteria to be adopted for that structure are not identified as regards

\section{Site characteristics}

The Estaleiro Rio Grande dry dock is $350.0 \mathrm{~m}$ long, $130.0 \mathrm{~m}$ high and 13.8 $\mathrm{m}$ deep below sea level. Its walls are 17.1 $\mathrm{m}$ high, including $3.3 \mathrm{~m}$ of free board in relation to the sea level.

Figure 1 (a) presents a view of the dry dock, where one can see the large gantry crane in operating position, with

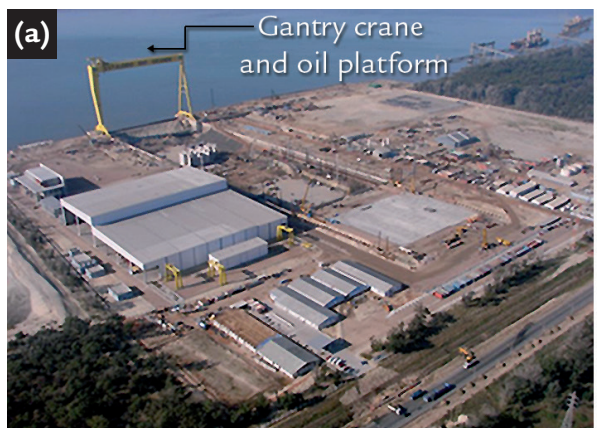

a drilling rig platform. Figure 1 (b) also shows a view of the dry dock. In this figure the size of the work can be seen, observing the space excavated as compared to a backhoe.

Figure 2 shows a schematic drawing of the Estaleiro Rio Grande shipyard dry dock, with the positioning of the drainage
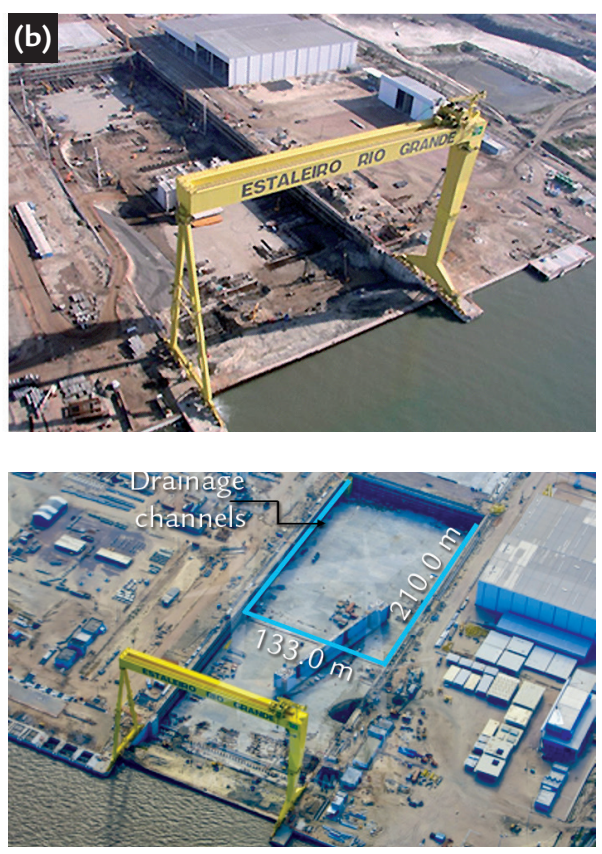

\section{Materials and methods}

\section{Rainfall intensity:}

The intensity-duration-frequency (idf) equation of the city of Rio Grande,

in which,

i s the maximum intensity of rainfall $(\mathrm{mm} / \mathrm{h})$ for a duration of $\boldsymbol{t}_{\min }$;

tr is the return-period of precipita- the return-period variable. Thus, an option is to perform a sensitivity analysis, adopting return-periods of 20,50 and 100 years.

This study is for the purpose of presenting a methodology to design the following questions must be asked cross section of the drainage channels, so that they will have the capacity to dampen an intense rainfall event; b) How much flow must be pumped in order to, together with the action of the drainage system project of a shipyard.
Rio Grande do Sul, was obtained from the paper presented by DAMÉ et al. (2006).

$$
i=\frac{k \cdot t r^{0,23}}{\sqrt{\left(2,25+t_{\min }\right)}}
$$

tion (years);

$\boldsymbol{t}_{\text {min }}$ is the duration of the rainfall event (minutes);

$\boldsymbol{k}$ is a parameter of the equation

drainage structures, keep the dry dock from flooding.

Several references show information about drainage system sizing. The following can be mentioned: AZEVEDO NETTO, J.M. and ALVAREZ, G.A. (1988), TUCCI, C.E.M. (1995), PORTO, R.M. (1999), TUCCI, C.E.M. (2002) BAPTISTA, M. and LARA, M. (2003), HOUGHTALEN, R.J. (2012). However, there are no studies (nationals or internationals) that present premises and criteria for the development of drainage systems in shipyard dry docks.

channels, for the purpose of collecting/ holding storm water, installed at the bottom of the structure. The drainage system consists of $553.0 \mathrm{~m}$ long channels:

- Two channels $210.0 \mathrm{~m}$ long, sideways to the dry dock;

- One channel 133.0 m long transversally to the dry dock.

Figure 1

(a) general view of the Estaleiro Rio Grande dry dock and (b) general view of the opening of the ditch to install the dry dock. Ref.: CEGLINSKI, J.P. (2014).

Figure 2

Positioning of the channels in relation to the dry dock. Ref.: BERNARDES, J. (2014).

The adjustment obtained in this case is shown in Equation 1:

obtained from the historical precipitation data. 
Table 1 presents the intensity values for rainfall events with 20, 50 and
100 years return-periods, and several durations of precipitation.
Table 1

Maximum rainfall intensity for the city of Rio Grande.

The channel system evaluated in this paper considered 35 durations of

\section{Drainage channels sizing:}

The storage volume of the drainage channels was determined from their total length and cross section, considering a rectangular section.

Initially, in order to determine the canal section, the sectors responsible for implementing the work were consulted. Based on the dimensions of the excavation equipment they recommended that

Table 2

Dimensions adopted for the set of drainage channels based on back time.

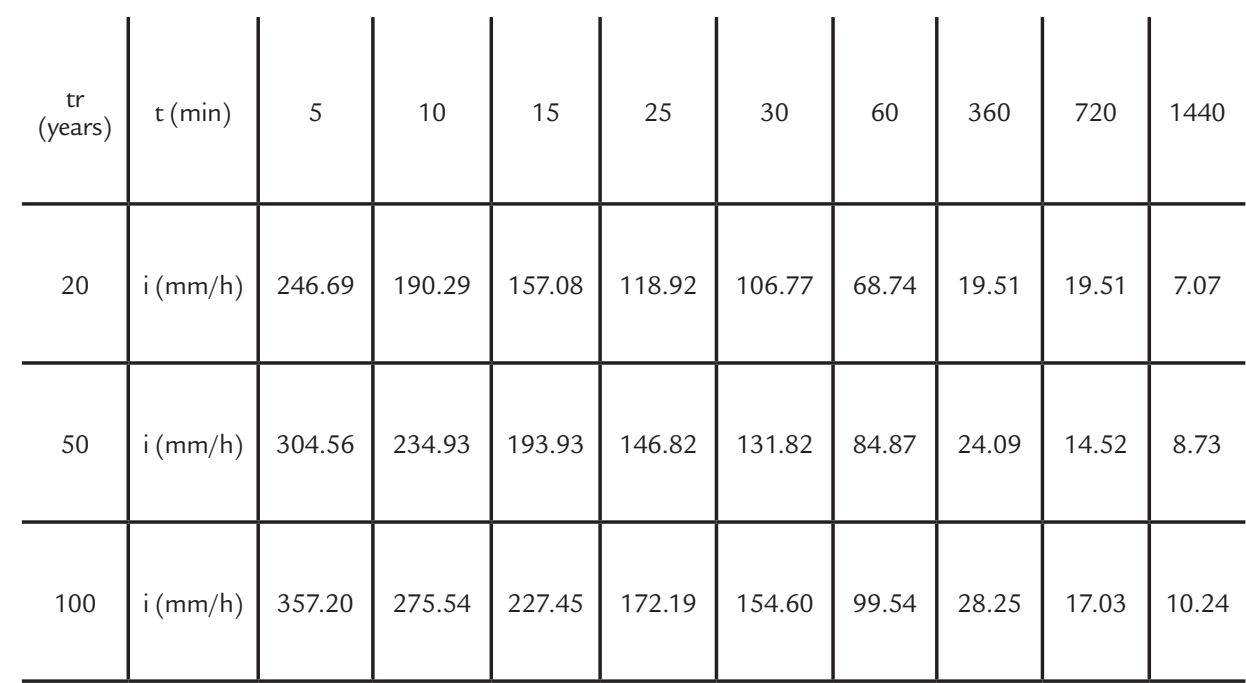

Source: Adapted from Damé et al. (2006). the incident rainfall events, ranging from $5 \mathrm{~min}$ to $175 \mathrm{~min}$ ( $2 \mathrm{~h} 55 \mathrm{~min}$ ), uniformly distributed along each duration.

Table 2 shows the sections rethe minimum width of the canal would be $1.50 \mathrm{~m}$. Likewise, the maximum depth should be in the order of $2.40 \mathrm{~m}$. From these boundary conditions, three different channel heights were tested $(1.00 \mathrm{~m}, 1.70 \mathrm{~m}$ and $2.40 \mathrm{~m})$ with the same width $(1.50 \mathrm{~m})$ under the occurrence of rainfall events of 20,50 and 100 years of return-period. ched and the respective accumulation volumes. The canal is a total of $553.0 \mathrm{~m}$ long. The channels filling profiles for recurrence periods of 20 , 50 and 100 year were obtained from a water balance considering the maximum rainfall intensity, the damping capacity of the channels and pumped flow.

\begin{tabular}{c|c|c|c}
$\operatorname{tr}($ years $)$ & Canal width* $(\mathrm{m})$ & Canal height $(\mathrm{m})$ & Canal volume $\left(\mathrm{m}^{3}\right)$ \\
\hline 20 & 1.50 & 1.00 & 829.5 \\
\hline 50 & 1.50 & 1.70 & 1410.2 \\
\hline 100 & 1.50 & 2.40 & 1990.8 \\
\hline
\end{tabular}

* Width defined by using the Caterpillar Backhoe 336 D L

\section{Pumping power:}

Pumping power in each case was obtained from equation 2:

In which,

Pot $_{\mathrm{b}}$ is the pump power $(\mathrm{kW})$;

The manometric height of the pumps was calculated by the sum of geometric height, equal to $13.8 \mathrm{~m}$, and the loss of total load in the circuit, estimated as $2 / 3$ of the pumping height, i.e., $9.20 \mathrm{~m}$. Thus the manometric height considered

$$
\operatorname{Pot}_{b}=\frac{9,81 \cdot Q \cdot H_{t o t a l}}{\eta_{b}}
$$

$\mathbf{Q}$ is the pumping flow $\left(\mathrm{m}^{3} / \mathrm{s}\right)$;

Htotal is the manometric height $(\mathrm{m})$;

was $22.0 \mathrm{~m}$.

From the previously described conditions and ignoring channels damping, the calculated pumping power for each pumping flow is shown in Table 3. These flow values were chosen from a prelimi- $\eta_{\mathrm{b}}$ is the pump yield (in this study adopted as $55 \%$ ).

nary analysis to avoid excessive dry dock flooding, which shouldn't be greater than $75 \mathrm{~mm}$ ( 3 inches) in any case but preferably lower than $10 \mathrm{~mm}$, and to avoid excessively large pumps, which would result in an excessive system cost. 


\begin{tabular}{c|c} 
Pumped flow $\left(\mathrm{m}^{3} / \mathrm{s}\right)$ & Power required by the pumps $*(\mathrm{~kW})$ \\
\hline 0.280 & 110 \\
\hline 0.300 & 120 \\
\hline 0.330 & 130 \\
\hline 0.350 & 140 \\
\hline 0.400 & 160 \\
\hline
\end{tabular}

* This is the power required by the set of pumps. It indicates that the system may comprise two or more pumps, depending on the flow, manufacturer or operational strategy and maintenance.

The system operation assumptions that pumps are turned on as soon as enough water height is available at the pumping intake, which would be designed and placed in such a way that it is reached from runoff almost at rainfall start. This means that power calculation considers full rainfall duration and channel storage is empty at

\section{Results}

Figures 3 to 11 show the results of simulations for the drainage channels with a rectangular cross section and a base equal to $1.50 \mathrm{~m}$ (due to constructive issues and excavation equipment commonly used in carrying out these large works) and heights equal to $1.00 \mathrm{~m}, 1.70$ $\mathrm{m}$ and $2.40 \mathrm{~m}$, corresponding to storage capacities equal to $829.5 \mathrm{~m}^{3}, 1410.2 \mathrm{~m}^{3}$ and $1990.8 \mathrm{~m}^{3}$, respectively, for different return-periods (20, 50 and 100 years). In all cases, the results of water depths and volume that overflowed onto the dry dock floor are presented. The vertical
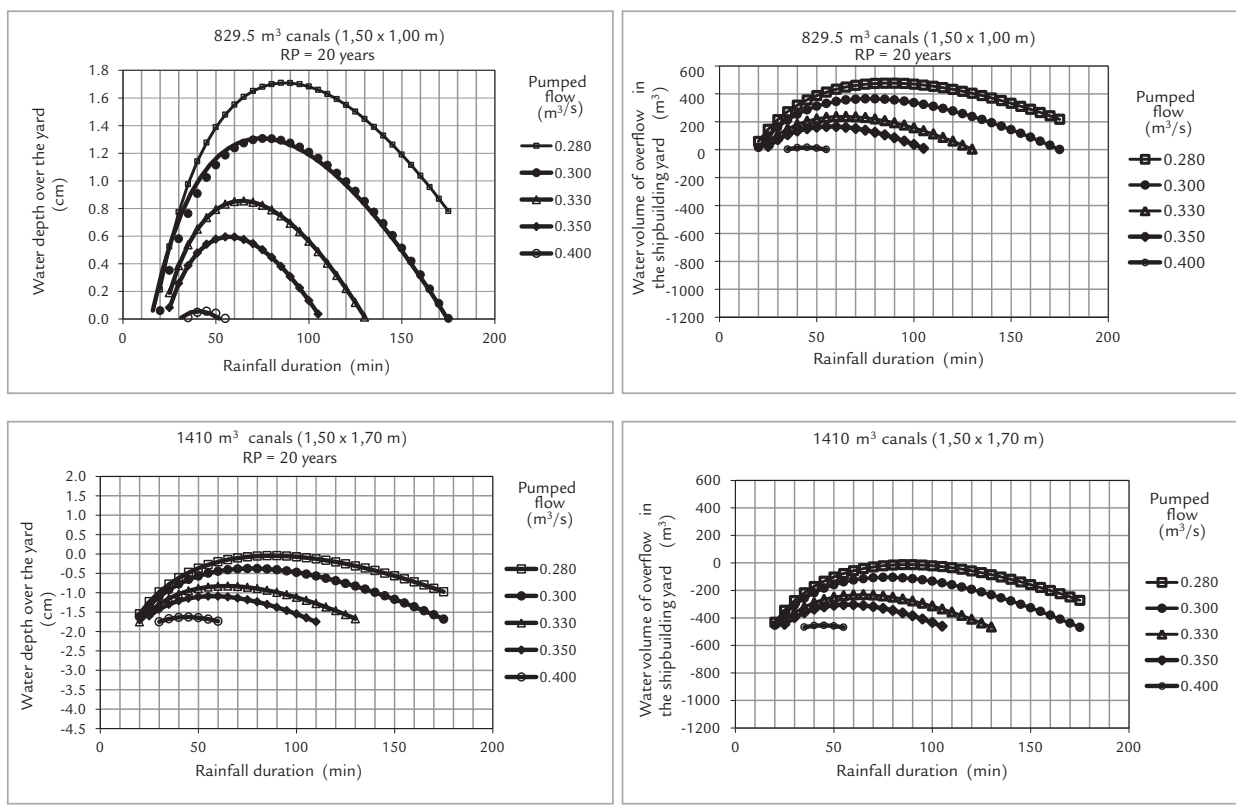

Table 3

Power required by the pumps and pumped flow.

fall events of 20, 50 and 100 years returnperiods. It should be emphasized that, in all cases, the use of the pumping system was considered with the hypotheses of installing pumps as shown in Table 3.

The remaining volumes during the rainfall events in the channels will later be pumped until the system is completely drained.

the damping of the flood event was considered for each scenario studied. Besides, as a premise, it was considered that before the flood event, the channel was empty (all storage volume can be used for flood damping).

The results obtained indicate that the channels that are $1.70 \mathrm{~m}$ high (storage equal to $1410.2 \mathrm{~m}^{3}$ ) and $2.40 \mathrm{~m}$ (storage equal to $1990.8 \mathrm{~m}^{3}$ ) do not overflow in rainfall events with a return-period of up to 20 years, considering the pumping hypotheses presented in Table 3.

Figure 3

Water depth and overflow volume for channels of $1.50 \mathrm{~m} \times 1.00 \mathrm{~m}$ and rainfall events with a 20 years return-period.

Figure 4

Water depth and overflow volume for channels of $1.50 \mathrm{~m} \times 1.70 \mathrm{~m}$ and rainfall events with a 20 years return-period. 
Figure 5

Water depth and overflow volume for channels of $1.50 \mathrm{~m} \times 2.40 \mathrm{~m}$ and rainfall events with a 20 years return-period.

Figure 6

Water depth and overflow volume for channels of $1.50 \mathrm{~m} \times 1.00 \mathrm{~m}$ and rainfall events with a 50 years return-period.

Figure 7

Water depth and overflow volume for channels of $1.50 \mathrm{~m} \times 1.70 \mathrm{~m}$ and rainfall events with a 50 years return-period.

Figure 8

Water depth and overflow volume for channels of $1.50 \mathrm{~m} \times 2.40 \mathrm{~m}$ and rainfall events with a 50 years return-period.

Figure 9 Water depth and overflow volume for channels of $1.50 \mathrm{~m} \times 1.00 \mathrm{~m}$ and rainfall events with a 100 years return-period.

Figure 10

Water depth and overflow volume for channels of $1.50 \mathrm{~m} \times 1.70 \mathrm{~m}$ and rainfall events with a 100 years return-period.
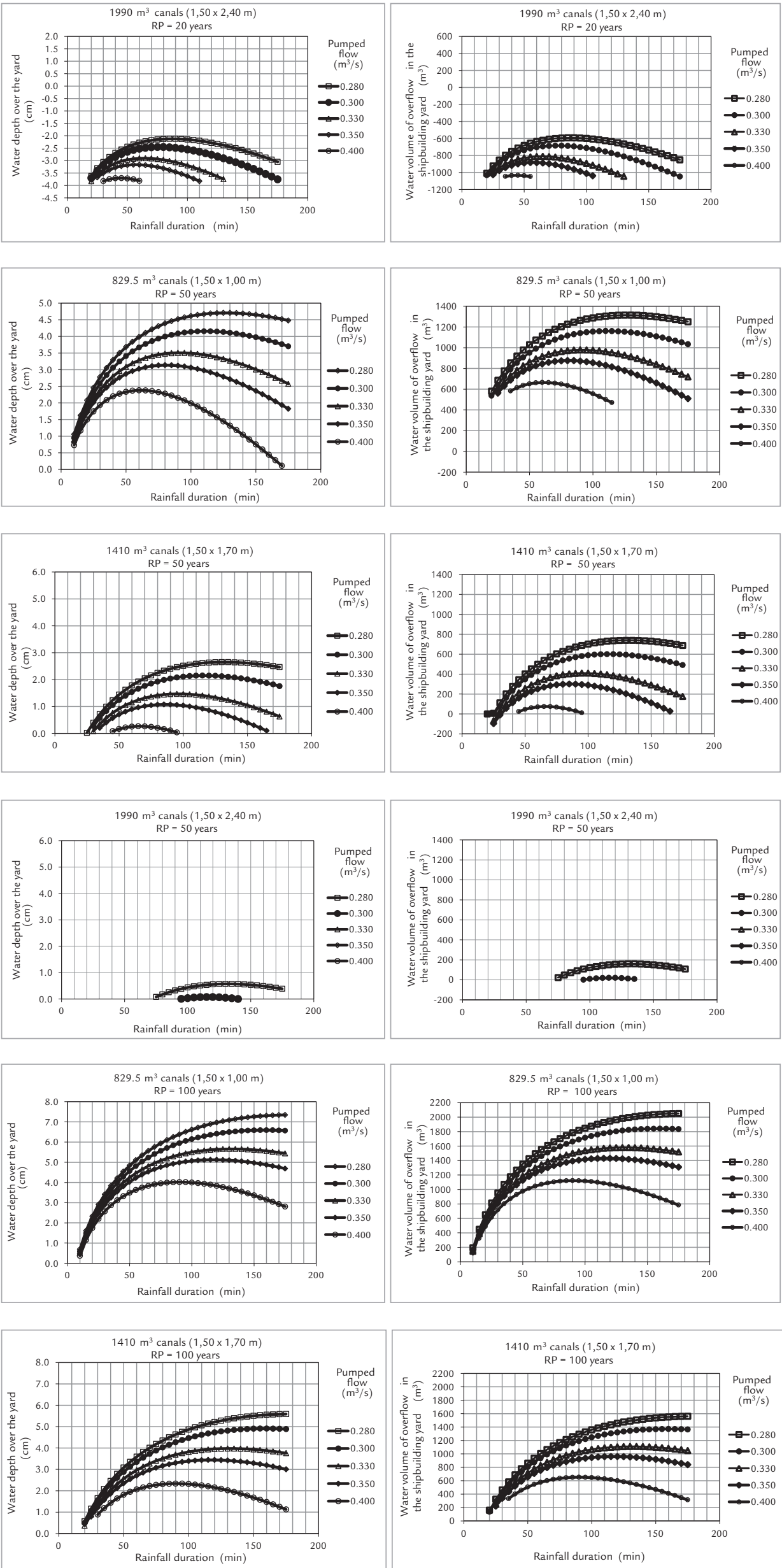


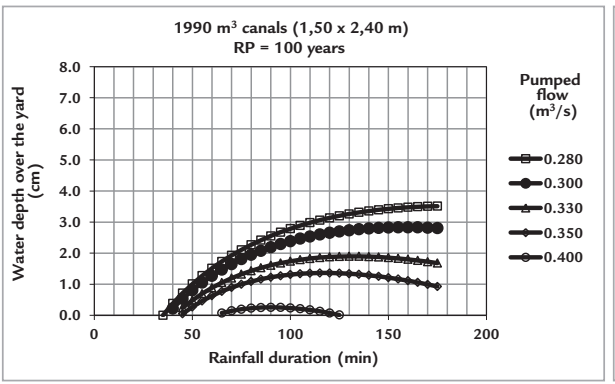

The results shown in Figures 3 to 11 are summarized in Tables 4 to 6 for a pumped flow of $0.28 \mathrm{~m}^{3} / \mathrm{s}$ and 7 to 9 for pumped flow of $0.40 \mathrm{~m}^{3} / \mathrm{s}$.

The analysis of Tables 4 to 6 shows that none of the channels have a water depth of less than $10 \mathrm{~mm}$ over the dry dock for a pumped flow of

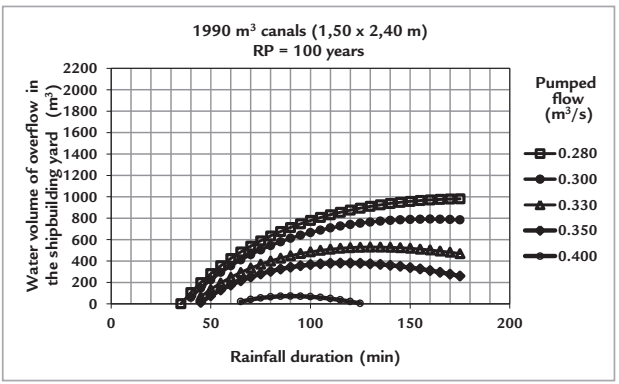

$0.28 \mathrm{~m}^{3} / \mathrm{s}$ and considering a 100 -year return-period. This $10 \mathrm{~mm}$ reference was taken as equivalent to half the height of a roller wheel of a small cart, typical of tool benches and small welding machines. Besides, this water surface is not enough to cover small tools, such as screw drivers and wrenches, and dam-
Figure 11

Water depth and overflow volume for channels of $1.50 \mathrm{~m} \times 2.40 \mathrm{~m}$ and rainfall events with a 100 years return-period.

age them.

On the other hand, Tables 7 and 9 show that storage of $1990.8 \mathrm{~m}^{3}(1.5 \mathrm{~m}$ x $2.4 \mathrm{~m}$ channel section) was needed for a pumped flow of $0.40 \mathrm{~m}^{3} / \mathrm{s}$ so that the water depth over the dry dock would not be higher than $10 \mathrm{~mm}$ from a rainfall event of 100 years return-period.
Pumped flow $=0.28 \mathrm{~m}^{3} / \mathrm{s}$

\begin{tabular}{c|c|c}
\hline rp(years) & Water depths $(\mathrm{cm})$ & Volumes overflown $\left(\mathrm{m}^{3}\right)$ \\
\hline 20 & 1.7 & 477 \\
\hline 50 & 4.7 & 1314 \\
\hline 100 & 7.3 & 2051 \\
\hline
\end{tabular}

$\mathrm{TH}$ - There is not

Pumped flow $=0.28 \mathrm{~m}^{3} / \mathrm{s}$

\begin{tabular}{c|c|c}
\hline rp (years) & Water depths $(\mathrm{cm})$ & Volumes of overflow $\left(\mathrm{m}^{3}\right)$ \\
\hline 20 & $\mathrm{TH}$ & $\mathrm{TH}$ \\
\hline 50 & 2.6 & 740 \\
\hline 100 & 5.6 & 1561 \\
\hline
\end{tabular}

$\mathrm{TH}$ - There is not

Pumped flow $=0.28 \mathrm{~m}^{3} / \mathrm{s}$

\begin{tabular}{c|c|c}
\hline rp (years) & Water depths $(\mathrm{cm})$ & Volumes of overflow $\left(\mathrm{m}^{3}\right)$ \\
\hline 20 & $\mathrm{NH}$ & $\mathrm{NH}$ \\
\hline 50 & 0.6 & 160 \\
\hline 100 & 3.5 & 981 \\
\hline
\end{tabular}

$\mathrm{TH}$ - There is not

Pumped flow $=0.40 \mathrm{~m}^{3} / \mathrm{s}$

\begin{tabular}{c|c|c}
\hline rp (years) & Water depths $(\mathrm{cm})$ & Volumes of overflow $\left(\mathrm{m}^{3}\right)$ \\
\hline 20 & 0.1 & 16 \\
\hline 50 & 2.4 & 664 \\
\hline 100 & 4.0 & 1122 \\
\hline
\end{tabular}

$\mathrm{TH}$ - There is not
Table 4

$1.50 \mathrm{~m} \times 1.00 \mathrm{~m}\left(\mathrm{~V}=829.5 \mathrm{~m}^{3}\right)$ channel.

Table 5

$1.50 \mathrm{~m} \times 1.70 \mathrm{~m}\left(\mathrm{~V}=1410.2 \mathrm{~m}^{3}\right)$ channel.

Table 6

$1.50 \mathrm{~m} \times 2.40 \mathrm{~m}\left(\mathrm{~V}=1990 \mathrm{~m}^{3}\right)$ canal.

Table 7

$1.50 \mathrm{~m} \times 1.00 \mathrm{~m}\left(\mathrm{~V}=829.5 \mathrm{~m}^{3}\right)$ canal. 
Table 8 $1.50 \mathrm{~m} \times 1.70 \mathrm{~m}\left(\mathrm{~V}=1410 \mathrm{~m}^{3}\right)$ canal.

Table 9

$1.50 \mathrm{~m} \times 2.40 \mathrm{~m}\left(\mathrm{~V}=1990 \mathrm{~m}^{3}\right)$ canal.

\section{Discussions}

The analyses performed indicate that, for the same pumping system, the channel dimensions should be about 60 $\%$ increased while the annual risk of overflow is reduced about 5 times when rainfall events sized with a 100 -year return-period are used, compared to the same system sized for rainfall events with a 20-year return-period.

On a 20-year horizon, estimated as these facilities lifetime, the probability of occurrence of overflow of a flume sized

Pumped flow $=0.40 \mathrm{~m}^{3} / \mathrm{s}$

\begin{tabular}{c|c|c}
\hline rp (years) & Water depths $(\mathrm{cm})$ & Volumes of overflow $\left(\mathrm{m}^{3}\right)$ \\
\hline 20 & $\mathrm{NH}$ & $\mathrm{NH}$ \\
\hline 50 & 0.3 & 74 \\
\hline 100 & 2.3 & 652 \\
\hline
\end{tabular}

$\mathrm{TH}$ - There is not

Pumped flow $=0.40 \mathrm{~m}^{3} / \mathrm{s}$

\begin{tabular}{c|c|c}
\hline rp (years) & Water depths $(\mathrm{cm})$ & Volumes of overflow $\left(\mathrm{m}^{3}\right)$ \\
\hline 20 & $\mathrm{NH}$ & $\mathrm{NH}$ \\
\hline 50 & $\mathrm{NH}$ & $\mathrm{NH}$ \\
\hline 100 & $\mathrm{NH}$ & $\mathrm{NH}$ \\
\hline
\end{tabular}

$\mathrm{TH}$ - There is not

for a 20 year return-period for events is $64 \%, 3.5$ times greater compared to the probability of failure of the structure sized for 100 year return-period events (18\%).

Thus, it is recommended for structures of the size of the Estaleiro Rio Grande dry dock:

- To size the channels and pumps system for rainfall events with a 100 year return-period;

- To adopt channels with a mean depth of $2.40 \mathrm{~m}$ and a width of $1.50 \mathrm{~m}$;
- To use submersible pumps to drain storm water, prepared to pump up to $0.40 \mathrm{~m}^{3} / \mathrm{s}$.

The authors also recommend that the maximum water depth accepted within the dry dock should not exceed $10 \mathrm{~mm}$.

Finally, in general, it is suggested to use a parallel pump array to allow modulating flow when less intense rainfall events occur, and thus reduce the number of pumping starts and extend the useful life of the pumps.

\section{Conclusions and recommendations}

The decision regarding the size of the pumping system and drainage/storage channels of a dry dock must be ruled by a set of premises and basic criteria that should be spelled out at the beginning of the project.

\section{References}

When developing an engineering solution, it is necessary to consider the hypothetical cost of paralyzing the activities of a dry dock, because this might cost more than implementing the respective drainage system (including installing the channels and pumping devices).

The incremental costs inherent to reducing the probability of occurrence of overflows may become very low, depending on the magnitude of the costs of stopping and repairing the damage caused.

AZEVEDO NETTO, J. M., ALVAREZ, G. A. Manual de Hidráulica. (7. ed.) São Paulo: Edgard Blücher, 1988. v. 1. 335 p.

BAPTISTA, M., LARA, M. Fundamentos de Engenharia Hidráulica. (2. ed.) Belo Horizonte: Editora da UFMG, 2003. 437 p.

BERNARDES, J. Dique seco. 2014. 1 fotografia, color. Rio Grande, 2014. Disponível em: <www.agenciapreview.com/detalheImagem.asp?cod_foto=11104>. Acesso em 30 jan. 2014.

IPEA (Instituto de Pesquisa Econômica Aplicada). Ressurgimento da indústria naval no Brasil (2000-2013). Brasília, 2014. 480 p.

CEGLINSKI, J.P. Dique seco. 2014. 1 fotografia, color. Rio Grande, 2014. Disponível em: <www.portoriogrande.com.br/site/imprensa_midia_galerias.php $>$. Acesso em: 30 jan. 2014.

DAMÉ, R. C. F. et al. Comparação entre curvas intensidade-duração-frequência de 
ocorrência de precipitação obtidas a partir de dados pluviográficos com aquelas estimadas por técnicas de desagregação de chuva diária. Revista Brasileira de Agrociência, Pelotas, v. 12, n. 4, p. 505-509, out./dez. 2006.

HOUGHTALEN, R.J., HWANG, NED H.C., AKAN, A.O. Fundamentals of Hydraulic Engineering Systems. (4. ed.) U.S.A.: Ed. Pearson, 2010. 494 p.

PORTO, R.M. Hidráulica Básica. (2. ed.) São Paulo: Editora EESC-USP, 1999.519 p.

TUCCI, C.E.M. (Org.). Hidrologia: ciência e aplicação. (3. ed.) Porto Alegre: Editora da UFRGS/ ABRH, 2002.943 p.

TUCCI, C.E.M. (Org.). Drenagem urbana. Porto Alegre: Editora da UFRGS/ABRH, 1995. $428 \mathrm{p}$.

Received: 06 November 2014 - Accepted: 02 March 2016. 